\title{
PERLINDUNGAN HAK PATEN DI INDONESIA
}

Velisa Nofelia

155100076

Fakultas Komputer, 448757168

Velisanofelia.student@umitra.ac.id

\begin{abstract}
Perbedaan sistem hukum perlindungan lingkup paten di berbagai negara, tidak hanya mengimpor investasi baru namun juga menentukan proses transfer teknologi suatu negara. Perlindungan yang meluas menyebabkan transfer teknologi menjadi tidak mudah walaupun kurangnya perlindungan karena pemilik paten mengalami kerugian. Kedua perbedaan niat tersebut menghasilkan perlunya studi komparatif tentang cakupan perlindungan paten di negara-negara. Ada dua masalah yang harus dijajaki, pertama apa perbedaan dan kesamaan cakupan perlindungan paten dalam peraturan negara dan yang kedua bagaimana sistem hukum mempengaruhi kejadian yang berbeda? Masalah ini akan menggunakan metode penelitian pendekatan statuta menyeluruh dan pendekatan komparatif, pendekatan kasus, dan pendekatan konseptual. Perbedaan proteksi paten dipengaruhi oleh sistem hukum common law yang lebih mengacu pada precident daripada civil law dengan kodifikasinya. Indonesia merumuskan cakupan proteksi paten yang masih terbatas yang terkait dengan terbatasnya kasus yang diselesaikan di pengadilan.
\end{abstract}

Kata Kunci : Hak Paten, Perlindungan Ruang Lingkup, Hukum Komparatif. 
A. INTRODUCTION

Perlindungan Paten Di Indonesia dari waktu ke waktu dilakukan penyempurnaan terhadap peraturan tentang hak paten. Dalam Pasal 2 UndangUndang No. 14 Tahun 2001, ditentukan:

(1)Paten diberikan untuk Invensi yang baru dan mengandung langkah inventif serta dapat diterapkan dalam industri.

(2)Suatu Invensi mengandung langkah inventif jika Invensi tersebut bagi seseorang yang mempunyai keahlian tertentu dibidang teknik merupakan hal yang tidak dapat diduga sebelumnya.

(3)Penilaian bahwa suatu Invensi merupakan hal yang tidak dapat diduga sebelumnya harus dilakukan dengan memperhatikan keahlian yang ada pada saat permohonan diajukan atau yang telah ada pada saat diajukan permohonan pertama dalam hal permohonan itu diajukan dengan Hak Prioritas. Substansi peraturan tersebut sama dengan peraturan yang berlaku sebelumnya melalui Undang-Undang No. 13 Tahun 1997. Hal yang membedakan bahwa UndangUndang No. 14 Tahun 2001 mengatur lebih tegas dan jelas. Dalam undang-undang ini, suatu Invensi dianggap baru jika pada tanggal penerimaan, Invensi tersebut tidak sama dengan teknologi yang diungkapkan sebelumnya, dengan syarat bahwa teknologi yang dimaksud telah diumumkan di Indonesia atau di luar Indonesia dalam suatu tulisan, uraian lisan atau melalui peragaan, atau dengan cara lain yang memungkinkan seorang ahli untuk melaksanakan Invensi tersebut sebelum tanggal penerimaan atau tanggal prioritas. Ditegaskan pula, teknologi dimaksud mencakup dokumen permohonan yang diajukan di Indonesia yang dipublikasikan pada atau setelah tanggal penerimaan yang pemeriksaan substantifnya sedang dilakukan, tetapi tanggal penerimaannya lebih awal daripada tanggal penerimaan atau tanggal prioritas permohonan. Insan Budi Maulana menyatakan, suatu penemuan baru yang tidak dapat dipatenkan:

a. Apabila bertentangan dengan moral termasuk moralitas agama, ketertiban umum, atau kesusilaan. Hal ini dicontohkan pada pengkloningan domba bisa ditolak penemuan patennya apabila penemuan itu bertentangan dengan agama. Hal yang sama dengan penemuan teknologi nuklir yang berkaitan dengan militer tidak dapat dipatenkan sebagaimana terjadi di jepang, tetapi jika berkaitan dengan pertanian dapat dipatenkan;

b. Apabila penemuan itu merupakan metode pemeriksaan, perawatan, pengobatan, dan pembedahan yang diterapkan terhadap 
manusia dan hewan, tetapi tidak menjangkau produk apapun yang digunakan, atau berkaitan dengan metode tersebut, seperti metode "terkun" untuk pengobatan;

c. Apabila penemuan itu merupakan teori dan metode di bidang ilmu pengetahuan dan matematika, seperti program komputer.

Di negara lain, seperti amerika serikat atau jepang, program komputer dapat dipatenkan. Nampak dari beberapa ketentuan berkenaan dengan syarat suatu penemuan paten diberikan, memiliki persamaan dengan pengaturan yang berlaku di negara-negara Eropa dan Jepang. Pengaturan Undang-Undang Paten Indonesia dalam menentukan luas perlindungan paten bila terjadi sengketa, belum bisa dinyatakan memiliki aturan yang jelas, apabila hanya mensyaratkan klaim yang harus dimuat di dalam permintaan paten yang diajukan dengan tanpa diberi penjelasan sedikit pun tentang klaim yang dimaksud, berdasarkan katakata dari klaim atau intisari dari klaim. Suatu perlindungan berdasarkan intisari klaim membawa konsekuensi perlindungan itu terlalu luas sehingga tertutup kemungkinan dilakukannya modifikasi meskipun bentuk dan wujudnya berbeda, karena dalam intisari klaim yang dipentingkan adalah fungsi penemuan yang sama.
Sebaliknya, apabila kata-kata dari klaim yang dilindungi memudahkan modifikasi tetapi mudah dilakukan peniruan. Seorang peniru hanya dengan mempelajari deskripsi yang mengungkapkan penemuan yang dipatenkan, dapat mengubah kata-kata dari klaim dan sekaligus mengadakan perubahan kecil yang tidak signifikan, tidak dianggap sebagai pelanggaran paten. Penafsiran demikian jelas tidak akan mempunyai arti bagi perlindungan pemegang paten yang dapat menimbulkan rasa enggan kepada penemu untuk meminta perlindungan melalui pendaftaran temuannya. Berdasarkan alasan ini, Peter mengajukan saran agar penafsiran terhadap klaim yang dimuat di dalam permintaan paten menggunakan penafsiran secara teleologis yaitu penafsiran didasarkan atas kepentingan yang dihadapi saat itu. Berdasarkan hal ini maka yang dilindungi bukan hanya kata-kata klaim tetapi juga bukan intisari klaim. Akan tetapi kata-kata dari klaim dijadikan landasan atau dasar, sedangkan deskripsi, gambar, dan abstraksi merupakan penjelasan dari klaim. Keuntungan dari penafsiran ini adalah peminta paten hendaknya merumuskan secara cermat dan tegas klaim yang dimintakan perlindungan. Di samping itu gambar, deskripsi, maupun abstraksi hendaklah mendukung kata-kata klaim 
tersebut. Begitu pula mengenai bentuk dan wujud juga menentukan perlindungan. Sedangkan fungsi bukan merupakan objek perlindungan sebab jika fungsi yang dilindungi akan menutup kemungkinan pihak lain untuk mendapatkan perlindungan paten bagi penemuan dengan fungsi yang sama. Penafsiran teleologis yang disarankan memberi makna pada persetujuan terhadap apa yang dilakukan oleh Jepang yang mengikuti Amerika serikat dalam penggunaan doktrin file wrapper estoppel dan equivalent. Indonesia sebagai penganut sistem hukum civil law bukan harga mati dalam mengadopsi sistem hukum common law. Lebih dari itu, jika dihubungkan dengan Hukum Adat Indonesia sesungguhnya lebih mendekati ke sistim hukum cammon law. Sekarang ini Indonesia dikenal sebagai penganut civil law, sesungguhnya hanya karena kecelakaan sejarah, yang kebetulan pernah dijajah oleh Belanda.

\section{B. CONCLUSION}

Perlindungan Paten Di Indonesia dari waktu ke waktu dilakukan penyempurnaan terhadap peraturan tentang hak paten.

Dalam undang-undang yang sekarang diterapkan, suatu Invensi dianggap baru jika pada tanggal penerimaan, Invensi tersebut tidak sama dengan teknologi yang diungkapkan sebelumnya, dengan syarat bahwa teknologi yang dimaksud telah diumumkan di Indonesia atau di luar Indonesia dalam suatu tulisan, uraian lisan atau melalui peragaan, atau dengan cara lain yang memungkinkan seorang ahli untuk melaksanakan Invensi tersebut sebelum tanggal penerimaan atau tanggal prioritas. Ditegaskan pula, teknologi dimaksud mencakup dokumen permohonan yang diajukan di Indonesia yang dipublikasikan pada atau setelah tanggal penerimaan yang pemeriksaan substantifnya sedang dilakukan, tetapi tanggal penerimaannya lebih awal daripada tanggal penerimaan atau tanggal prioritas permohonan.

Indonesia hanya menyebutkan secara umum tanpa merinci lingkup perlindungan - dari segi kata-kata dalam klaim atau intisari (substansi) klaim yang menjadi pegangan hakim. Sistem hukum common law banyak mempengaruhi perlindungan hak paten secara sempit. Pengaruh civil law system hanya sebatas dalam bentuk pengaturan luas perlindungan hak paten melalui undang-undang yang tidak mengikat pengadilan setiap negara, kecuali Jerman yang secara kaku berpegang pada kodifikasinya. 


\section{ACKNOWLEDGEMENT \\ University Of Indonesia \\ University Of Mitra Indonesia \\ Telkom University \\ University Of Mellbourne \\ Saitama University}

\section{REFERENCE(Based ISO 690 )}

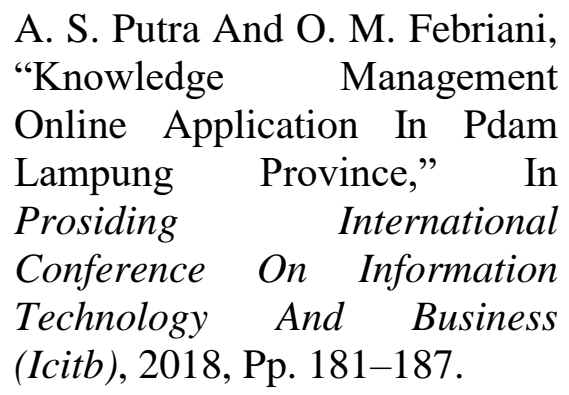

A. S. Putra, O. M. Febriani, And B. Bachry, "Implementasi Genetic Fuzzy System Untuk Mengidentifikasi Hasil Curian Kendaraan Bermotor Di Polda Lampung," J. Sist. Inf. Dan Manaj. Basis Data, Vol. 1, No. 1, Pp. 21-30, 2018.

[3] O. M. Febriani And A. S. Putra, "Sistem Informasi Monitoring Inventori Barang Pada Balai Riset Standardisasi Industri Bandar Lampung," J. Inform., Vol. 13, No. 1, Pp. 90-98, 2014.

[4] Putra, Arie Setya. "2018 Artikel Struktur Data, Audit Dan Jaringan Komputer." (2018).

[5] Putra, A. S. (2018, July 17). Paperplain Fundamental Create Application With Borland Delphi 7.0 University Of Mitra Indonesia. Retrieved From Osf.Io/Pbrn9.

\section{E. REFERENCE (Based APA)}

Putra, A. S., Aryanti, D. R., \& Hartati, I. (2018, November). Metode SAW (Simple Additive Weighting) sebagai Sistem Pendukung Keputusan Guru Berprestasi (Studi Kasus: SMK Global Surya). In Prosiding Seminar Nasional Darmajaya (Vol. 1, No. 1, pp. 85-97).

Sari, D. P., Febriani, O. M., \& Putra, A. S. (2018, November). Perancangan Sistem Informasi SDM Berprestasi pada SD Global Surya. In Prosiding Seminar Nasional Darmajaya (Vol. 1, No. 1, pp. 289-294).

Putra, A. S. (2018). Paperplain: Execution Fundamental Create Application With Borland Delphi 7.0 University Of Mitra Indonesia.

Putra, A. S., Sukri, H., \& Zuhri, K. Sistem Monitoring Realtime Jaringan Irigasi Desa (JIDES) Dengan Konsep Jaringan Sensor Nirkabel. IJEIS (Indonesian Journal of Electronics and Instrumentation Systems), 8(2), 221232.

Darmawan, A., Yuliawati, D., Marcella, O., \& Firmandala, R. (2016). Sistem Absensi dan Pelaporan Berbasis Fingerprint dan SMS Gateway. EXPLORE, 7(1).

Febriani, O. M., Wahyuni, T., \& Yusuf, S. (2017). DESIGN OF 


\section{WEBSITE-BASED INFORMATION SYSTEM FOR EDOCUMENT ADMINISTRASI IN THE COMMUNITY SERVICE UNIT (A Case Study at Rajabasa District). INTERNATIONAL JOURNAL OF COMPUTERS \& TECHNOLOGY, 16(7), 7010-7020.}

Febriani, O. M., \& Wahyuni, T. (2017, October). PERANCANGAN SISTEM E-DOCUMENT ADMINISTRASI LOGBOOK PENELITIAN PADA UNIT LAYANAN DI BANDAR LAMPUNG. In Prosiding Seminar Nasional Darmajaya (Vol. 1, No. 1, pp. 187-194).

Febriani, O. M., \& Permadi, A. B. (2017). Implementasi Sistem Aplikasi Data Bimbingan dan Pelanggaran Siswa pada Sekolah Menengah Atas di Lampung Tengah dengan Metode Analisis dan Desain Sistem Terdistribusi (SSAD). EXPERT, 7(1).

Febriani, O. M., \& Ambarwati, L. (2015). PERANCANGAN APLIKASI PENGOLAHAN DATA PENJUALAN UKM KELANTING KHAS TELO DESA SIDOHARJO KECAMATAN JATI AGUNG KABUPATEN LAMPUNG SELATAN. Jurnal Teknologi Informasi dan Bisnis Pengabdian Masyarakat Darmajaya, 1(1), 77-95.

Febriani, O. M. (2015). Rancang Bangun Aplikasi Ecommercemenggunakan Freewebstore pada UKM Kelanting di Desa Sidoharjo Lampung Selatan. Prosiding Sembistek 2014, 1(02), 446-458. 